\title{
Religious based education of Islamic elementary school, being competitive with market management strategies
}

Wahyudhiana

IAIN Salatiga

wahyudhiana@yahoo.co.id

DOI: 10.18326/mudarrisa.v10i1.1-24

\begin{abstract}
Education is the foremost factor to escalate nation esteem, so all countries in the world are intense in developing education system to meet the more complexity of life. This research aims to find out the phenomena of educational institution managed as an industry or corporation in terms of positioning, management branding, management marketing, marketing strategy, promotion strategy, in order to achieve customer satisfaction by improving the education quality as intangible services from industrial perspective. The research context takes place in Islamic Elementary School, Madrasa Ibtidaiya Istiqomah (MII) Sambas Purbalingga as a religious based education with competitive and marketable market management strategies, and it has 1.329 students in 38 classes. This research belongs to qualitative descriptive in which the researcher actively involves in the location by interviewing the informants and taking documentation to support the research. The result shows that the school is excellent and prominent, professionally organized by the management of customer satisfaction orientation with management patterns and models: Total Quality Management, Madrasa Based Management and ISO Management (International Standard Organization). The principles of school marketing management focus on: 1) positioning, attaching in customer mind; 2) differentiation, different from conventional program and; 3) branding, maintaining the brand. Those are the attractiveness toward customers to enroll their children in this institution.
\end{abstract}

Keywords: educational industry, religion, market management, marketable 


\section{INTRODUCTION}

Education is the keyword in accelerating personal values and nation esteem, and the advancement of education can be a parameter of a nation development and an indicator of its prosperity. In the management discussion, leadership and human resources have significant roles especially as an effective leader, or even as an educational institution leader surely needs qualified staff as well (Isjoni, 2007). As the requirement in this globalization era, it is required qualified human resources that possess skills and intentions to respectively develop their quality (Yogaswara, 2010). From the current data by the researcher from forty three countries, almost all life aspects in Indonesia are in the last ten on the list (E. Mulyasa, 2003: 1).

Many cases of juvenile delinquency, school gang fight, drugs, killing, sexual harassment are getting rampant in our country. Globalization also affects in the crisis of morality and characters, criminality and free sex among teenage. According to Sarlito Wirawan Sarwono, in Abdurrahman al Mukaffi, (1995: 95) states that $80 \%$ sex intercourse out of marriage occurs at home, $11 \%$ at hotel, $4,9 \%$ in the park and 2,8 at school, the rest in the car and somewhere else. This truth makes parents anxious about their future. Meanwhile, in the case of school gang fight, between July to September 2012, 13 students are passed away on the fight (Kompas, 16 September 2012).

On case of nation official, the most intriguing scene is corruption that worsen Indonesian image in international perspective. As the data 
from Political Economic Risk Consultancy atau PERC, Indonesia is the most corrupted countries out of 14 (fourteen) investment destination countries in Asia Pacific (Sri Nawatmi, 2014: 73-82).

In retrospect to those shabby portraits, it is considerable that some people blame the field of education. Therefore, the burden of educational institutions specifically Islamic education school, madrasa, becomes more intense. As religion based education institution, education in madrasa is not only in the purpose of transferring of knowledge but also transferring of (Islamic) Values (Azra, 1998). In the meantime, Islamic education institution is working with many challenges called as the word of Abd. Rachman Assegaf, 'intelectual dead lock' (Sisdiyanto, 2006: 6).

One of the important factors is the problem of managerial from madrasa officers which is qualified or not qualified. The fluctuation is extreme and imbalance between public officers of state madrasa with private madrasa as in the data from the magazine Ikhlas Beramal from the Ministry of Religious Affairs 2008. The number of public Madrasa Ibtidaiya (MI) in Indonesia are 1.567 schools (7,4 \%), 19.621 schools of private MI (92,6\%), 1.259 schools of Public Islamic Secondary Schools (MTs) (9,8\%), 11.624 schools of private MTs (90,2 \%), 644 schools of public Islamic Senior High (Madrasa 'Aliyah) (11,9\%), 4.754 schools of private Madrasa 'Aliyah (88,1 \%) (M. Firdaus, 2009: 9). They keyword of madrasa quality challenges is on the madrasa management which is proper and professional. 
According to Jamal Ma'mur Asmani (2015: 16), the challenges in the global era become more complex and require responses by the advent of qualified educational institutions. Schools as educational service providers need to take lesson learn and initiate to improve customer satisfaction by having proper and proportional madarasah management because education is a circular process that reciprocally gives effects and simultaneously occurs (Supar, 2014: 160). Qualified school is a dream of all nation elements because it will graduate high qualified students that will bring nation revolution. According to Sudarwan Danim dalam Alfiatun Khasanah (2015: 162), qualified schools must focus on customer satisfaction.

Royan M. (2007:254) argues that each new product should have marketable containers instead of product setting segmentation, targeting and positioning toward competitor markets. Consecutively, it is to decide the product pricing; upper or under the competitor price. Also, it is to design precise distribution channel in order to achieve maximum distribution as stated in the vision and mission of the company. Therefore, the quality improvement becomes the major challenge in every type, level, and model of education to provide life meaning, and marketing turns into one of the movement quality for that development (Khasanah, 2015: 162).

Those conditions motivate the researcher to conduct a research on management quality in Madrasa Ibtidaiya Istiqomah Sambas Purbalingga. The latest survey data reveal 1.329 students of MI Istiqomah Sambas in 2016 in 38 classes, with varied social economic background of students. 
The phenomena inspire the researcher to evaluate the formula used by the madrasa, mainly derived from the marketable quality of educational performance.

\section{The trend of contemporary education quality management}

The approach of customer satisfaction

The management of an educational institution as that of industry of corporation becomes a trend in this globalization era. Educational institutions work like industry or company that involve methods of: positioning, branding management, marketing management, market take over strategy, school promotion strategy as the effort to gain customer satisfaction.

Edward Sallis (2012) in Total Quality Management in Education has initiated the approach of education quality improvement as intangible service with corporation and education industry approach. Initially, the brand is dominated by companies, entrepreneurs, and business practitioners. They posit brand as an ultimate weapon to deliver the charms of their products. The company management works at best to convey their products in many ways; advertisement, brochure, and events. One of their purposes is to acknowledge their brands or their products (Mulyana: 2012).

School Marketing Strategy

Marketing is a branch of knowledge that is formerly dominated by companies and business practitioners to offer and sell their products, but 


\section{Mudarrisa: Jurnal Kajian Pendidikan Islam, Vol. 10, No. 1, 2018}

it does not happen any longer as education field need marketing knowledge. Educational officers and practitioners require mastering marketing knowledge properly. By so doing, schools are capable to offer their products effectively and efficiently. Marketing strategy summarized in Phillip Kotler (2009) includes the formula AIDA; Awareness, Interest, Desire, Action. Awareness means developing awareness on the significance of the products as the need for everyone. Interest create awareness to have desire to the product derived from the product attractiveness. Desire appears as the attractive factors of the product. Action is a strong intention to bear action. (Kotler, 2009: 86). The strong intention is actualized through positioning, differentiation, branding as a smart method to develop schools.

Positioning is an effort to persuade customer minds using company and corporation products. Similarly, schools persuade customers to have interest and compassion to the schools. The ability to define positioning is an effort to persuade consumer minds with qualified school offers (Hari Wijaya \& Hani Sirine, 2016).

Differentation means creating different activities from other people in order to support positioning and increase branding values. In executing marketing strategy, specifically school marketing, it should not be similar with other schools strategies. In promoting schools, marketing teams must be able to create different strategies. Differentiation will result excelent value to customers, and they will have more interest to proposed products (Mulyana, 2012 : 20). 
Branding becomes an identity or characters of typical schools, mainly with the strengths and differentiation, that adhered specifically to the schools. Keller (2003) stated brand as a name, term, sign, symbol or plan to identify products or services.

The strategy in developing school reputation An educational institution with reputation, prestige, marketable values is everyone dream. If we want to have reputable, expensive branded, respectable educational institution, we have to make those credits (Robandi, 2008). According to Mulyana (2012), in order to have strong brand, schools must be well prepared and pre designed properly by all school staff.

The implementation of Total Quality Management (TQM)

The management that orients to quality and customer satisfaction is well known as Total Quality Management (TQM) or integrated quality management. It is a proper option in organization, working unit or modern company with holistic philosophy created based on the concepts of quality, team work, productivity, and customer satisfaction. Therefore, this approach will substitute the conventional management position.

\section{Religion based education}

Religious values is an important factor of high attractiveness for parents and stake holders because they want their children to be pious, have prominent religious integrity, be religious, and to have noble characters in this global era encountering the phenomena of free sex, drugs, IT 
advancement (gadget, laptop, notebook etc.) that seemingly contain violence and pornography (Tuzzahrah, F. F. Komariyah, K. \& Sani, A. 2016: 37$58)$.

Education with religious orientation is predicted as an option for parents to put their children in the era of global transformation. Based on Allah saying related to the issue of education as in Qs. At Tahrim 66: 6

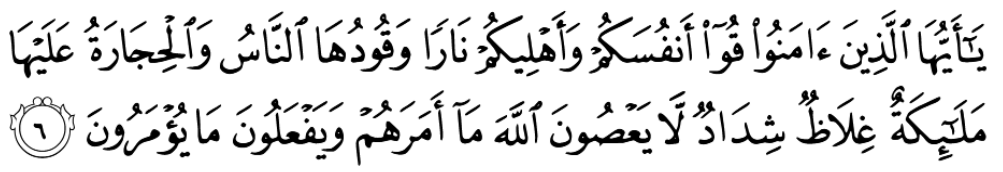

"O you who have believed, protect yourselves and your families from a Fire whose fuel is people and stones, over which are [appointed] angels, harsh and severe; they do not disobey Allah in what He commands them but do what they are commanded."

In other verse of Qs. Maryam 19: 59, Allah says:

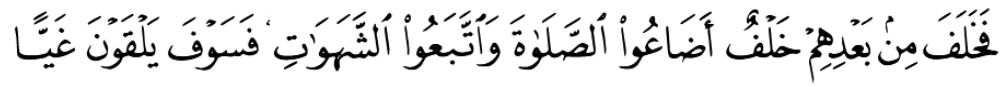

"But there came after them successors who neglected prayer and pursued desires; so they are going to meet evil",

In other verse of Qs. An Nisaa 4: 9 Allah says:

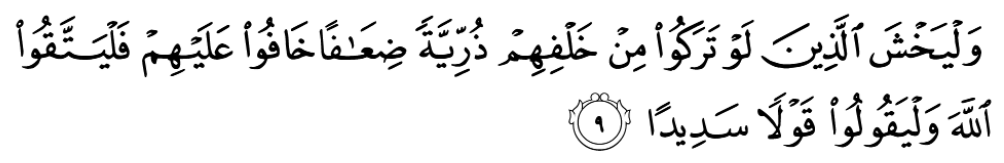

"And let those [executors and guardians] fear [injustice] as if they [themselves] had left weak offspring behind and feared for them. So let them fear Allah and speak words of appropriate justice" 


\section{The perspective of Islam on human}

Islam views humans as their meaning, so they have life guidelines to assure happiness and prosperity in the mortal world and hereafter, physically and spiritually, personally and collectively. Human is as an integrity of feeling, mind, heart, and physic (Rachmawati, 2012). Human needs to connect with God, and the relation with God is in the frame of faith through religion and prayer as in the guidelines (Basyir \& Azhar, 2003: 35). Islam teaches the truth that humans possess physical and spiritual aspects, and living in this world toward after life should treat proportionally, balance and in harmony as in Allah saying of Qs. Al-Baqarah 2: 201

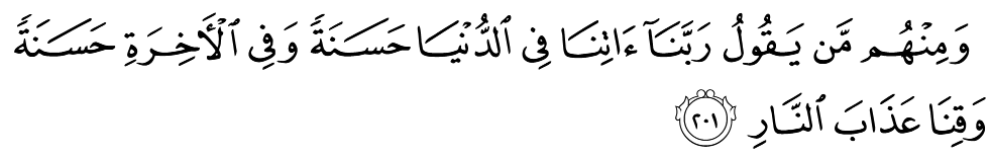

"..But among them is he who says, "Our Lord, give us in this world [that which is] good and in the Hereafter [that which is] good and protect us from the punishment of the Fire".

In line with that verse, Islam teaches human to seek after life happiness, but it should not forget the mortal world bliss. Allah says in Qs. Al Qashash 28: 77,

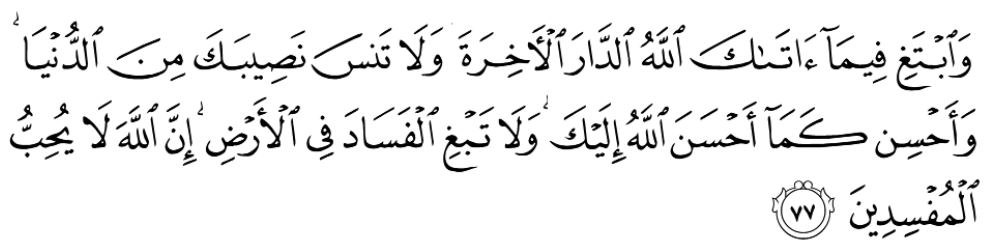

"But seek, through that which Allah has given you, the home of the Hereafter; and [yet], do not forget your share of the world. And do good as 
Allah has done good to you. And desire not corruption in the land. Indeed, Allah does not like corrupters".

Islam treats humans meaning as an integral parts of body and soul, physic and spirit. Each of which is an independent substance, but it requires other substances to actualize. From this concept, Islamic education plays its role to highlight the potentials from spirit, physic, soul as their proportion obliged by the religion (Muhajir, 2015).

\section{METHODS}

This research belongs to descriptive qualitative. According to Moleong (2006:157) and Basrowi \& Suwandi (2008:169), the primary data of qualitative research are words and field action, and the rest are secondary data such as documents and the like. It means that data resources of qualitative research can be categorized into three groups; the personals, environment or the observable, and documentation. Based on the above theories, the researcher personally visits the research site, interviews the informants, and populates documents to support research data.

The research location is in Madrasa Ibtidaiya Istiqomah Sambas Purbalingga, and it is conducted in July to August 2016 by populating data from related informants; Madrasa principals, Madrasa vice principals of Islamic deed and performance affairs, Madrasa vice principals of academic affairs, Madrasa vice principals of institution management affairs, and Madrasa vice principals of students affairs. In addition, the committee of Istiqomah Sambas foundation, parents and 30 students engage in 
interview sessions. The technique of data population applies interview method, observation, documentation study, and relevant reference to MI Istiqomah Sambas Purbalingga. By this research, it will contribute academic information about the quality education concept and contemporary management concept in madrasa.

Meanwhile, the data analysis technique is by process organizing and putting in order into patterns, categories, and basic serial standard to find out themes, so it can formulate working hypothesis as in stated by the data (Moleong, 2006). The analysis is a process to sort out, choose, delete, categorize date in the purpose of answering two main research problems namely; 1) what themes derived from the data; 2) how many data support the themes (Basrowi \& Suwandi, 2008). The concluding process from the populated data is the form of precise sentences and provides clear meaning. The conclusion statement can be initiated from tentative conclusion that requires improvement by data validity technique.

\section{DISCUSSION}

The area of Purbalingga regency is among 35 regencies or cities in the province of Central Java. This regency shares the North border with Pemalang regency, the East and South borders with Banjarnegara regency, and the West border with Banyumas regency. The wide of Purbalingga regency is 77.764 .122 ha or $777,64 \mathrm{~km} 2$, lies in East longitude: $109^{\circ} 11^{\prime} \mathrm{BT}$ - $109^{\circ} 35^{\prime}$ BT and South altitude: $7^{\circ} 10$ LS - $7^{\circ} 29^{\prime}$ LS. The minimum average temperature is $24,3^{\circ} \mathrm{C}$, and the maximum average temperature is 
$31,7^{\circ} \mathrm{C}$. whereas, the humidity is approximately $85 \%$. The precipitation is normally 123 days of $3.130 \mathrm{~mm}$. This area is $40 \mathrm{~m}$ until $3.000 \mathrm{~m}$ high from the sea level.

In Purbalingga regency, there are many elementary schools (SD), public and private Islamic elementary schools (MI); 461 public SD, 5 private SD, 3 public MI, 175 private MI. in total, there are 644 schools. Total population of Purbalingga regency is 894.062 people. Meanwhile, the index of human development consists of 5 components; a) Human development index (percentage): 66,23\%; b) the number of life expectancy (year): 72,80; c) annual expense (rupiah) : 8.359; d) education expectancy (year) : 11,51; e) the average of education tenure (year) : 6,84 (Suprapto, 2015).

\section{The advent of the foundation of Istiqomah Sambas Purbalingga}

The foundation of "Istiqomah Sambas" is established in 12 October 1999, focusing on the field of education, social and religion. The initiator is $\mathrm{H}$. Suchari Adi Mulyono (RIP) with his family. Based on the current anxious condition, H. Suchari Adi Mulyono (RIP) with this family intent and determine to participate in developing Islamic adherence by establishing a foundation in the field of education, social, and religion. Respectively, in 28 June 2000, Madrasa Ibtidaiya Istiqomah (MII) Sambas is officially established by the Regent of Drs. Triyono Budi Sasongko, M. Si, and accommodates 164 students (Profile MII Sambas: 2005). 
The vision of MII Sambas is: "Recognizing quality for prominent school, Being a role model and Religious". Whereas, the indicators include 1) accommodating students with normal intelligence (normal) and taking students through prominent process to gain high grade result; 2) structuring Moslem scholars with noble characters, wide perspective, open, skilful and creative; 3) becoming a reference for other schools and institutions, and continuously raising innovative ideas in the field of education confronting world challenges; 4) creating Islamic ambience in all aspects inside and outside of schools involving teachers, parents, guardians, and surrounding environment.

The mission of MII Sambas Purbalingga is to provide maximum and optimal education services to all students: 1) providing qualified teaching and learning activities; 2) providing professional teaching staff; 3) providing representative structures and infrastructures; 4) providing clean, safe, comfortable, and orderly arrangement of environment; 5) developing spiritual to improve the quality of faith and god fearing to all school staff; 6) upholding discipline; 7) maintaining harmonic relation with parental association, government, society, and business world; 8) implementing quality management system; 9) utilizing laboratory and library.

\section{Empowering Madrasa in Islamic Practices}

Empowering madrasa in the field of religion or Islamic practices and activities becomes the important factor in achieving customer satisfaction. In this case, parents feel fortunate from those practices from teachers and 
students (Soegito, 2011). Those activities gain acceptance from parents, yield satisfaction due to the real practices from their children, and create typical "positionong" in customer heart.

To name of few, the running programs are as follow: 1) the custom of expressing Islamic greeting (salam) to anyone; 2) the custom of shaking hands to anyone; 3) offering main prayer collectively in the boarding house or madrasa hall; 4) praising to God before the meal and learning eating ethics; 5) learning courtesy and ethics meeting other people; 6) the custom of praising the God before and after studying; 7) forwarding right foot to enter classrooms and stepping up stairs; 8) forwarding left foot leaving classroom and stepping down stairs; 9) daily basis invocation for student daily practice; 10) the custom of giving on a certain stipulated days.

Instead of those daily programs, MII Sambas also has special programs in the field of Islam religion: 1) memorizing Quran for 5 chapters during the period of education; 2) learning Al Qur'an using 'UMMI' method with the facilities: a) teacher certification of ummi methode; b) learning management; c) learning evaluation; d) learning supervision; e) examination to test the ability; 3) learning nahwu shorof (Arabic grammar and structure) using 'Tamyiz' method to give understanding on Al Qur'an; 4) qiro'atul kutub for certain students; 5) learning speech and teen preachers; 6) qiro'ah al Qur'an; 7) singing religious songs or hadroh; 8) commemorating Islamic monumental days; 
9) short pesantren and romadhon practices; 10) visiting parents that will depart for Hajj or Umroh; 11) giving social charity for the unfortunate.

MII Sambas is organized professionally involving Madrasa based management (MBM), Total Quality Management (TQM) or integrated quality management, Marketing Management using ISO international management, and the foremost empowering religion of Islam. The reinforcement of religion is as the foundation of madrasa, and intentionally applies in daily practices. It has been proven as the important factor to satisfy customers. The activities are accepted and fill the hunger of the parents. They feel satisfy toward the religious practices of their children in daily basis, so the condition has special "positionong" in the heart of customers (parents).

In terms of quality policy of MII sambas; firstly, educational service quality is to structure prominent, creative, religious students as the basic principle in managing education in MII Sambas that is consecutively developed following the world development. Secondly, in order to maintain consistency of the policy implementation, MII Sambas applies a quality management system focusing on simultaneously improvement of all aspects especially the aspect of teacher professionalism. Thirdly, the directors and staff commit in implementing and achieving all vision and targets related to quality policy.

The management patterns of Madrasa Ibtidaiya Istiqomah (MII) Sambas 
MII Sambas occupies several school management patterns to support the achievement of madrasa vision; with quality standard, being a prominent, role modelling, religious. The management patterns include madrasa based management (MBM) that orients to independent characters and madrasa autonomy, especially in decision making process, total quality management (TQM) that orients to continous quality improvement and customer satisfaction, the expectation of parents and stake holder satisfaction.

Total Quality Management (TQM)

Total Quality Management is an management approach or organization focusing on quality, on the basis of all staff participation, and in the purpose of long term success derived from customer satisfaction and benefit sharing for all staff in the organization and society (Islami \& Sudaryanto, 2017).

MII Sambas always maintains trust from its customers (parents) and society by continuously fulfilling the customer expectation and providing high quality education services. Periodically, madrasa distributes questionnaire to parents containing expectation from parents in order to meet people hope especially the parents. MII Sambas also retains the relationship with parents intensively by having consultation program that occurs periodically in each semester.

Madrasa Based Management (MBM/MBS)

This management pattern is by giving greater (authority and responsibility) to schools, giving flexibility and encourage direct participation of school 
staff including teachers, students, principals, administration staff, parents, society, scholars, businessmen to contribute in developing madrasa quality based on national education policy and related law (Dita Novelina Risno, 2015). Thus, MII Sambas employs Madrasa Base Management (MBM) by optimizing the strengths of human resources and other resources, and determines independent policy that is in line with related regulation.

Management ISO (International Standard Organisation)

Officially, MII Sambas has applied management ISO ISO 9001: 2008 since 2010 after acquiring ISO certificate 9001: 2008 No: D004.1.104.1.11 from ISO certification institution DELTA PAS INTERNATIONAL that takes into effect for 3 years, and has been reevaluated in 2013 with the certificate No.D004.1.104.02.14.

There is dualism management system in MII Sambas although it has applied quality management system ISO 9001: 2008. It is possible because this institution follows "One System in Management Policy". This management focuses on international organisation standard. MII Sambas implements that strategy to provide consistent educational service in the purpose of improving achievement.

\section{Marketing Management}

Marketing management executed by MII Sambas is preceded with process of defining marketing purposes by considering internal resources and market opportunity, planning and activity implementation to meet those purposes and evaluate the development. 
The MII Sambas efforts are namely: a) creating special programs amid parents; b) intensive communication to stake holder; parents in periodic meeting on Sundays starting $06.00-08.00 \mathrm{am}$ in the morning; c) giving information and publication with the method of visitation 'silaturrahim' and empowering with the meeting program of achievement consultation 'konsultasi prestasi belajar peserta didik' (KPBPD) with parents; d) initiating the program after Tadzkir or collective learning, in the format of religious programs; e) maintaining communication and interaction with customers or parents to create trust and invite other customers; d) from that process, the actualization of simple marketing concept, the system of Mouth to Mouth "Gethok-Tular" amid the community of parents and possible customers that spread in several districts in Purbalingga regency, even from other regency.

Moreover, the other marketing management is to inform school achievements and awards participated by students telling their experience. From this process, the parents trust rise to put their children in this school. The achievement of MII Sambas can be described in Table 1 .

Table 1. The list of achievement of MII Sambas at district level

\begin{tabular}{clcl}
\hline No & \multicolumn{1}{c}{ Achievement } & Year & \multicolumn{1}{c}{ Description } \\
\hline 1. & $1^{\text {st }}$ place of Drum Band & 2003 & Banyumas district level \\
& SD/MI & & \\
2. & $\begin{array}{l}\text { Favourite winner English story } \\
\text { telling }\end{array}$ & 2007 & Banyumas district level \\
3. & $2^{\text {nd }}$ Math subject & 2007 & Banyumas district level \\
4. & $5^{\text {th }}$ Math subject & 2007 & Banyumas district level \\
5. & $5^{\text {th }}$ English subject & 2007 & Banyumas district level \\
6. & $5^{\text {th }}$ Science subject & 2008 & Banyumas district level \\
7. & 3th Science subject & 2008 & Banyumas district level \\
8. & $5^{\text {th }}$ Math subject & 2008 & Banyumas district level \\
\hline
\end{tabular}




\begin{tabular}{clll}
\hline 9. & $5^{\text {th }}$ English subject & 2008 & Banyumas district level \\
10. & $4^{\text {th }}$ English subject & 2008 & Banyumas district level \\
11. & $1^{\text {st }}$ English subject & 2008 & Banyumas district level \\
12. & $2^{\text {nd }}$ English subject & 2008 & Banyumas district level \\
13. & $3^{\text {rd }}$ solo singer & 2008 & Banyumas district level \\
14. & $1^{\text {st }}$ religious singer & 2014 & Banyumas district level \\
15. & $2^{\text {nd }}$ female solo singer & 2014 & Banyumas district level \\
16. & $2^{\text {nd }}$ Math subject & 2014 & Banyumas district level \\
17. & $2^{\text {nd }}$ Tae Kwondo & 2015 & Banyumas district level \\
18. & $3^{\text {rd }}$ English subject & 2016 & Banyumas district level \\
19. & $2^{\text {nd }}$ Math subject & 2016 & Banyumas district level \\
20. & $3^{\text {rd }}$ Math subject & 2016 & Banyumas district level \\
21. & $3^{\text {rd }}$ Reciting Quran (Tilawah) & 2016 & Banyumas district level \\
22. & $3^{\text {rd }}$ Reciting Quran (Qiro'ah) & 2016 & Banyumas district level \\
\hline
\end{tabular}

Table 2. The list of achievement of MII Sambas at Central Java Province

\begin{tabular}{llll}
\hline No & \multicolumn{1}{c}{ Achievement } & Year & Description \\
\hline 1. & $1^{\text {st }}$ Adzan \& Iqomah & 2001 & Province level \\
2. & $1^{\text {st }}$ Teacher modelling & 2003 & Province level \\
3. & $1^{\text {st }}$ healthy school (SD/MI) & 2003 & Province level \\
4 & $1^{\text {st }}$ healthy school (MI) & 2003 & Province level \\
5. & $6^{\text {th }}$ Science Olympiad & 2005 & Province level \\
6. & $2^{\text {nd }}$ Arabic speech & 2009 & Province level \\
7. & Finalist of OSN & 2013 & Province level \\
8. & $1^{\text {st }}$ KSM & 2014 & Province level \\
9. & $2^{\text {nd }}$ Badminton & 2015 & Province level \\
10. & $2^{\text {nd }}$ intelligence quiz of UMP & 2016 & Province level \\
11. & $1^{\text {st }}$ School Pot awards & 2016 & Province level \\
12. & $1^{\text {st }}$ Science Madrasa & 2016 & Province level \\
\hline
\end{tabular}

With those lists, MII Sambas is confident and possesses more motivation to work and gain more achievement.

Table 3. The list of achievement of MII Sambas

\begin{tabular}{clcl}
\hline No & \multicolumn{1}{c}{ Achievement } & Year & Description \\
\hline 1. & $2^{\text {nd }}$ healthy school & 2005 & National level \\
2. & $3^{\text {rd }}$ Madrasa Award & 2005 & National level \\
3. & $1^{\text {st }}$ Madrasa Award & 2012 & National level \\
4. & Finalist of online Olympiad & 2014 & National level \\
5. & $2^{\text {nd }}$ KSM & 2014 & National level \\
6. & Finalist of online Olympiad & 2015 & National level \\
\hline
\end{tabular}




\begin{tabular}{lllc}
\hline 7. & $1^{\text {st }}$ Online Olympiad & 2016 & National level \\
8. & $1^{\text {st }}$ Madrasa Science Computer & 2016 & National level \\
9. & $4^{\text {th }}$ Math subject & 2016 & IMSO International \\
\hline
\end{tabular}

From the fact of achievements and awards of MII Sambas at district, regency, province, national, and international level, it becomes the evidence as the prominent madrasa and professionally organized institution focusing on customer satisfaction; parents as one of the stake holders.

The principles of school Marketing Management such as Positioning of "product" MII Sambas are imprinted on the mind of customers. The program of differentiation is different from other conventional school programs, and Branding is to maintain "brand" as part of the effort of MII Sambas although it emphasizes more on practical level. With such management as explained above, MII Sambas Purbalingga has developed into a prominent madrasa at district level with 43 awards, regency level with 41 awards, Karesidenan level (Integrated several regencies) with 22 awards, Central Java Province level with 12 awards, national level with 8 awards, and Silver medal of International Math competition, and $4^{\text {th }}$ International Mathematics And Science Olympiad (IMSO) $13^{\text {th }}$ year 2016 in Jakarta, at elementary school level with the theme: "Smart, Skilled, and Creative in Joyful Competition for Excelent". The participants come from 22 countries including Bulgaria, the Netherlands, Brunei Darussalam, South Korea, China, Hongkong, Nepal, 
Laos, Malaysia, South Africa, Srilangka, Singapore, Mongolia, Taiwan, Iran, India, Kazakhstan, and Indonesia.

The result of this research describes that MII Sambas Purbalingga is as a prominent educational institution that belongs to Moslem, manages professionally on the basis of religion of Islam, powerful and competitive in regency, national, and international levels. The student number of MII Sambas Purbalingga are increasing annually. In 2016, the total students are 1.329 people accommodated in 38 classes, and it is predicted escalating every year. The reason is that parents believe the school to put their children in this institution related to successful education process.

\section{CONCLUSION}

MII Sambas occupies spirit and determination as the foundation of institution to achieve the true happiness in the world and hereafter that is practiced by the foundation leaders and followed by Madrasa principals, and all teachers. Performing in this madrasa is in the spirit of developing "the mortal world for hereafter happiness". The motivation is to graduate Islamic young generations with god fearing and noble characters, discipline, intellectuality, emotional capability, sympathy, empathy, spiritual capability, national loyalty, and respectable toward Indonesia Republic (NKRI).

By implementing religious practice properly and intuitively, MII Sambas has proven to create typical attractiveness toward parents as the main customers to put their children in this institution through the 
management models and patterns of Total Quality Management, Madrasa Based Management dan Management ISO (International Standard Organisation). Regarding the increasing student number annually, it requires a prayer facility such as bigger Mosque to accommodate all students. The championship event of IMSO in 2016 should be the starting point to go international and publicize MII Sambas Purbalingga through communication written forum and International Conference. Eventually, the international world will acknowledge that one of the best madrasa is in Indonesia

\section{REFERENCES}

Asmani, J. M. (2015). Manajemen Efektif Marketing Sekolah Pertama. Yogyakarta: Diva Press.

Azra, A. (1998). Pembaharuan Pendidikan Islam. Jakarta: Ditjen Binbaga Islam.

Basyir, A. A. (2003). Falsafai Ibadah Dalam Islam. Yogyakarta: UII Press.

Basrowi \& Suwardi (2008). Mamahami Penelitian Kualitatif. Jakarta: Rineka Cipta.

Brazer, D. S. \& Keller, L. R. (2006). A Conceptual Frimwork For Multiple Stake holder Education Decesion Making, International Journal of Education Policy E Leadership. 1 (3). 1-14.

Departemen Agama RI. (2012). Al Qur'an dan Terjemahnya, Jakarta: Departemen Agama.

Fattah, N. \& Sa'ud, U.S. (2010) Kontribusi Manajerial Kepala Sekolah dan Sstem Informasi Kepegawaian Terhadap Kinerja Guru, Jurnal Penelitian Pendidikan. 11 (2). 62-76.

Harian Kompas, Jakarta: 16 September 2012

Khasanah, A. (2015). Pemasaran Jasa Pendidikan Sebagai Strategi Peningkatan Mutu di SD Alam Baturraden, El-Tarbawi, 8 (2). 161176. 
Kertajaya, H. (2007). On Positioning, Bandung: PT. Mizan Pustaka.

Isjoni. (2007). Manajemen Kepemimpinan Dalam Pendidikan, Bandung: Sinar Baru Algesindo

Islami, K. \& Sudaryanto, B. (2017). Pengaruh Penerapan Total Quality Management (TQM) Untuk Mengurangi Pengembalian Pekerjaan (Job Return) Sebagai Usaha Dalam Memenuhi Kepuasan Pelanggan. Diponegoro Journal Of Management. 6 (2). 1-8.

Muhajir. (2015). Jasmani Manusia Dalam Perspektif Para Ahli Pendidikan. Jurnal Qathruna. 2 (2). 87-120.

Mulyana, A.Z. (2012). Reformation Marketing Sekolah, Surabaya: Bening Pustaka.

Moleong, L. (2006). Metodologi Penelitian Kualitatif, Bandung: PT Remaja Rosdakarya.

Mulyasa, E. (2003). Pedoman Manajemen Berbasis Madrasa, Jakarta : Ditjen Bagais.

MII Sambas. (2015). Profil Madrasa, Purbalingga: MII Sambas.

Nawatmi, S. (2014). Korupsi dan Pertumbuhan Ekonomi Negara-Negara Asia Pasifik. Jurnal Bisnis dan Ekonomi (JBE). 21 (1). 73-82.

Rachmawati. Y. (2012). Pendidikan Karakter Melalui Pengembangan Model Pembelajaran RKCK (Rasa Karsa Cipta Karya). Journal Pendidikan Anak. 1 (1). 21-30.

Rahman, M. (2011). Metode Penelitian Pendidikan Moral, Semarang: Unnes Press.

Risno, D. N. (2015). Implementasi Manajemen Berbasis Sekolah Pada Aspek Peran Serta Masyarakat di Sekolah Menengah Atas Negeri 1 Padang. Bahana Manajemen Pendidikan. 3 (2). 777-785.

Robandi, I. (2008). Becoming The Winner, Yogyakarta: CV. Andi Offset. Royan, M. F. (2007). Smart Launching New Product. Jakarta: Gramedia.

Sallis, E. (2012). Total Quality Management In Education. Yogyakarta: IRCiSoD.

Sisdiyanto, S. M. (2006). Pendidikan Islam di Era Transformasi Global, Jakarta: Ditjen Binbaga Islam.

Sugiyono. (2008). Metode Penelitian Kuantitatif, Kualitatif dan $R \mathcal{E} D$, Bandung: Alfabeta.

Sukardi. (2008). Metodologi Penelitian Pendidikan, Jakarta: PT. Bumi Aksara. 
Mudarrisa: Jurnal Kajian Pendidikan Islam, Vol. 10, No. 1, 2018

Sukmadinata, N. S. (2011). Metode Penelitian Pendidikan, Bandung: PT. Remaja Rosdakarya.

Sumintono, B. (2013). Sekolah Unggulan: Pendekatan Pengembangan Kepala Sekolah. Jurnal MP. 2 (1), April.

Supar, (2014). Marketing Strategy Integrated Islamic Elementary School Nurul Fikri Tulungagung. Journal Humanity. 10 (1). 158-170.

Suprapto. (2015). MI Istiqomah Sambas, Profile Of Superior Madrasa In Purbalingga Regency. Edukasi. 13 (2). 291-311.

Tuzzahrah, F. F. Komariyah, K. \& Sani, A. (2016). Konstruksi Makna Sekolah Islam bagi Orang Tua Siswa. Ilmu Dakwah, Academic Journal for Homiletic Studies. 10 (1). 37-58.

Thohari, H. (2005). Suchari: Membangun Dunia Untuk Akhirat, Purbalingga: Sambas Publisher.

Wijaya, H. \& Sirine, H. (2016). Strategi Segmenting, Targeting, Positioning Serta Strategi Harga Pada Perusahaan Kecap Blekok Dicilacap. AJIE, Asian Journal Of Innovation and Entrepreneurship. 1 (3). 175-190. 